\title{
RANCANG BANGUN SISTEM PAKAR UNTUK MENENTUKAN KEGIATAN EKSTRAKURIKULER BERDASARKAN MINAT DAN BAKAT SISWA SEKOLAH MENENGAH PERTAMA
}

\author{
Arih Juha Suaeban ${ }^{1}$, Fenty E.M.A ${ }^{2}$, Anif Hanifa Setianingrum ${ }^{3}$ \\ ${ }^{1,2,3}$ Program Studi Teknik Informatika, Fakultas Sains dan Teknologi \\ Universitas Islam Negeri (UIN) Syarif Hidayatullah Jakarta \\ Jl. Ir. H. Juanda No. 95, Ciputat 15412 Telp. (+62-21) 7493606
}

\begin{abstract}
ABSTRAK
Guru menginginkan hasil yang terbaik utnuk siswa didiknya, salah satunya yaitu dalam penentuan ekstrakurikuler bagi siswanya. Terkadang siswa memilih ekstrakurikuler berdasarkan kebanyakan temanya. Padahal penentuan ekstrakurikuler sangat penting dalam mengembangkan bakat yang dimiliki siswa. Sistem pakar penentuan ekstrakurikuler terhadap minat dan bakat siswa sekolah menengah pertama membantu para guru dalam menentukan ekstrakurikuler yang cocok untuk siswanya berdasarkan minat dan bakat siswa. Sistem ini menggunakan teknik depth-first search untuk menentukan ekstrakurikuler yang cocok bagi siswa.
\end{abstract}

Kata Kunci: Sistem Pakar, Depth-First Search, Unified Modelling Language (UML)

\section{PENDAHULUAN}

Sebagai seorang guru tentu menginginkan hasil yang terbaik untuk murid didiknya. Terkadang guru tidak mengerti bakat dan minat siswanya. Sebagian besar guru melihat kecerdasan seorang siswa dari tes IQ dan nilai pendidikan formal, dan seringkali mereka mengeluhkan nilai anak didik mereka yang kurang memuaskan. Siswa yang tidak memiliki nilai pendidikan formal yang bagus bukan berarti mereka malas dan tidak akan berguna, mungkin bakat dan kecerdasan mereka memang terletak pada bidang lain seperti seni, olah-raga, dan lain-lain yang bobot pada pendidikan formal tidak terlalu besar.

Peran pendidikan Indonesia dalam menangani anak berbakat diluar pendidikan formal yaitu dengan menyediakan fasilitas pendidikan ekstrakurikuler di tiap sekolah. Namun penentuan pemilihan ekstrakurikuler diserahkan sepenuhnya pada siswa tanpa ada campur tangan guru maupun orang tua. Hal ini memperbesar kemungkinan ketidakcocokan ekstrakurikuler yang siswa pilih karena pada umumnya siswa akan memilih ekstrakurikuler berdasarkan mayoritas keinginan temanya, hal ini dapat dilihat dari jumlah anggota antar ekstrakurikuler yang berbeda sangat jauh, seperti anggota sepak bola akan jauh lebih banyak dari anggita teater atau ekstrakurikuler seni lainya, padahal mungkin ada banyak siswa yang berbakat dalam teater namun masuk ke estrakurikuler lain karena ikut temanya. Karena itu pemahaman kecocokan ekstrakurikuler sangatlah penting agar bakat siswa dapat dikembangkan dengan baik. Sehingga kemudian hari siswa akan dengan bakatnya mengharumkan nama bangsa dan sekolahnya.
Oleh karena itu Aplikasi Sistem Pakar Penentuan Ekstrakurlikuer Terhadap Minat dan Bakat Siswa Sekolah Menengah Pertama ditujukan untuk membantu pada guru untuk menentukan kegiatan ekstrakurikuler yang cocok bagi siswa mereka.

\section{LANDASAN TEORI}

\section{Sistem Pakar}

Menurut Muhammad Arhami (2005:9) system pakar (expert system) merupakan paket perangkat lunak atau paket program computer yang ditujukan sebaga penyedia nasehat dan sarana bantu dalam memecahkan masalah dalam bidang-bidang spesialisasi tertentu seperti sains, perekayasaan matematika, kedokteran, pendidikan dan sebagainya.

\section{Metode Depth-first Search}

Merupakan teknik penelusuran data pada node-node secara vertical dan sudah terdefinikan, misalnya dari kiri kenkanan (Hartono, 2003:16). Depth-first search melakukan penelusuran kaidah secara mendalam dari simpul akar bergerak menurun ke tingkat dalam yang berurutan (Arhami, 2005:20).

\section{Probabilitas}

Probabilitas adalah peluang suatu kejadian, yaitu: suatu ukuran tentang kemungkinan suatu peristiwa (event) akan terjadi di masa mendatang. Probabilitas dinyatakan dengan nilai 0 sampai 1 atau dalam presentase. Probabilitas merupakan suatu cara kuantitatif yang berhubungan dengan ketidakpastian yang telah ada sejak abad ke 17. Teori probabilitas diperkenalkan oleh Pascal dan Fermal pada tahun 1654 (Parrat, 1961). 
Sifat probabilitas:

$$
0 \leq(A) \leq 1
$$

Simbol $P$ digunakan untuk melambangkan nilai probabilitas dari suatu kejadian. Dengan demikian P(A) menyatakan probabilitas bahwa kejadian A akan terjadi dalam observasi atau percobaan tunggal. Nilai probabilitas terkecil adalah 0 (ini menyatakan suatu kejadian tidak mungkin terjadi) dan nilai probabilitas tertinggi adalah 1 (ini menyatakan suatu kejadian yang pasti terjadi).

Ada tiga pendekatan konsep untuk mendefinisi-kan probabilitas dan menentukan nilai-nilainya, yaitu:

\section{- Pendekatan Klasik}

Pendekatan klasik didasarkan pada banyaknya kemungkinan-kemungkinan yang dapat terjadi pada suatu kejadian. Setiap peristiwa mempunyai kemungkinan yang sama untuk terjadi. Rumus probabilitas:

Banyaknya outcome memenuhi A, banyaknya outcomes keseluruhan

$$
P(A)=\frac{\text { banyaknya outcome memenuhi } A}{\text { banyaknya outcomes keseluruhan }}
$$

\section{- Pendekatan Relatif}

Dengan pendekatan ini nilai probabilitas ditentukan atas dasar proporsi dari kemungkinan yang terjadi dalam suatu observasi atau percobaan. Tidak ada asumsi awal tentang kesamaan kesempatan, karena penentuan nilai-nilai probabilitas didasarkan pada hasil observasi dan pengumpulan data. Konsep frekuensi relative, yaitu jika eksperimen dilakukan $\mathrm{n}$ kali, dan event A teramati f kali, maka rumusnya:

$$
P(A)=f / n
$$

\section{- Pendekatan Subjektif}

Pendekatan subjektif dalam penentuan nilai probabilitas adalah tepat apabila hanya ada satu kemungkinan kejadian yang terjadi dalam satu kejadian. Dengan pendekatan ini, nilai probabilitas dari suatu kejadian ditentukan berdasarkan tingkat kepercayaan yang bersifat individual dengan berlandaskan pada semua petunjuk yang dimilikinya.

\section{Multiple Intelegent}

Teori Multiple Intelligence diperkenalkan pada tahun 1983 oleh Dr. Howard Gardner, guru besar di bidang Psikolog dan Pendidikan Harvard University. Dr. Gardner menyebutkan bahwa intelegensi (kecerdasan) bukanlah suatu kesatuan tunggal yang bias diukur secara sederhana denga test IQ. Dr. Gardner mendifinisikan intelegensi sebagai suatu kapasitas untuk memecahkan permasalahan atau membentuk produk yang bernilai dalam satu atau lebih latar budaya (Prasetyo, 2009). Untuk aplikasi ini akan mengambil 5 kecerdasan sebagai batasan masalah, yaitu kecerdasan linguistic, visual spasial, kinestetik, musical, dan naturalis.

\section{Aptitude}

Bakat (Aptitude) adalah kemampuan bawaan yang merupakan potensi yang masih perlu dikembangkan atau dilatih untuk mencapai suatu kecakapan, pengetahuan, dan ketrampilan khusus (Lucy, 2010).

\section{ANALISA DAN PERANCANGAN SISTEM}

Perancangan aplikasi menggunakan UML yang merupakan Bahasa standar untuk memodelkan aplikasi yang dibangung dengan metodologi berorientasi objek.

\section{a) Use Case Diagram}

Gambaran system ditampilkan dalam Use Case Diagram. Ada 2 Kelompok user pada aplikasi yaitu user daftar (pengajar) yang dapat mendaftarkan dirinya melalui aplikasi dan administrator yang bertugas melakukan pengaturan terhadap seluruh data di aplikasi.

- Pendaftaran Anggota

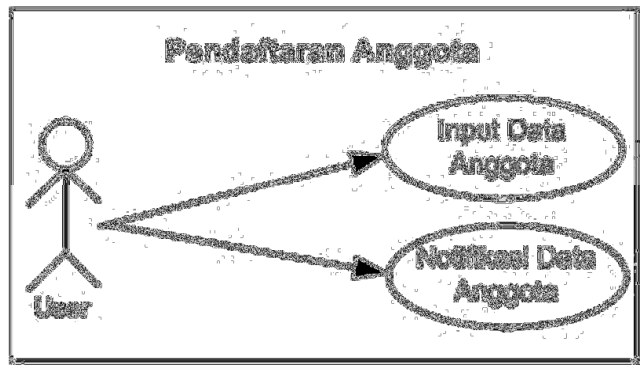

Para tenaga pengajar dapat mendaftarkan dirinya secara online melalui aplikasi.

- Konsultasi Ekstrakurikuler

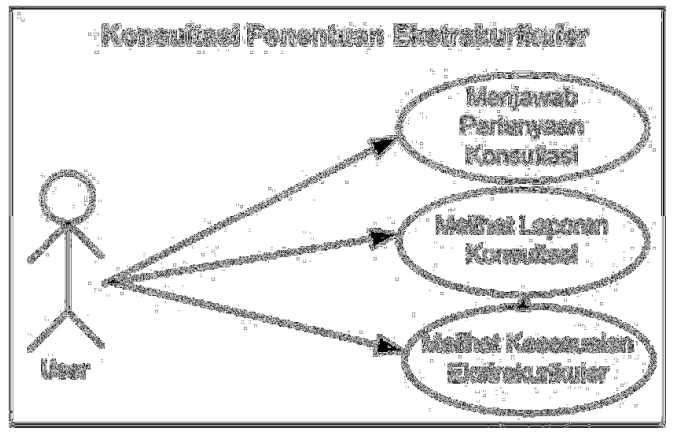


Setelah pengajar mendaftar dapat melakukan konsultasi penentuan ekstrakurikuler, pertanyaanpertanyaan yang di ajukan seputar bakat dan kebiasaan siswa didiknya.

- Management Angggota: untuk mengelola (melihat, edit dan hapus) data anggota

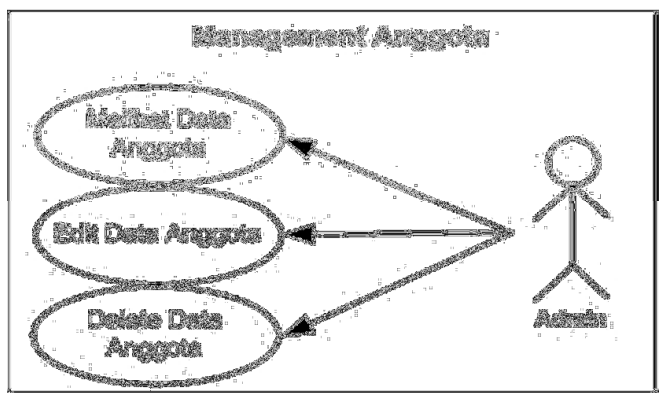

- Management Tipe Kecerdasan: untuk mengelola (melihat, edit dan hapus) tipe kecerdasan siswa.

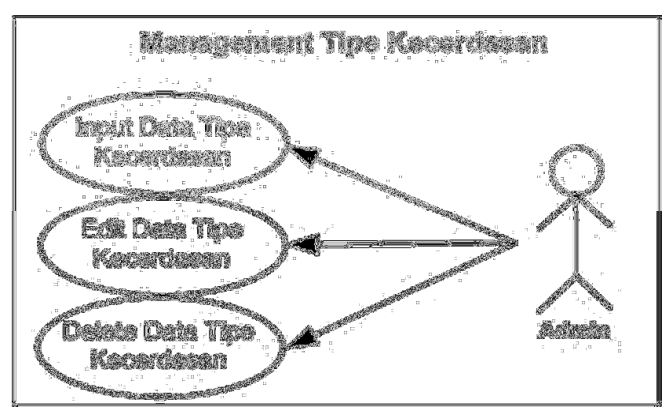

- Management Ekstrakurikuler: untuk mengelola (melihat, edit dan hapus) data ekstrakurikuler.

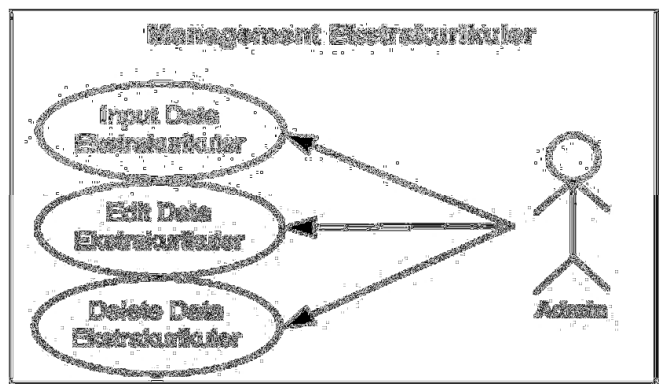

- Management Pertanyaan: untuk mengelola (melihat, edit dan hapus) data pertanyaan.

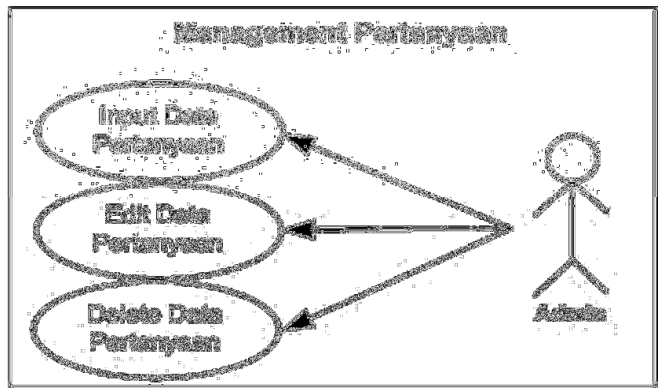

- Management Aturan: untuk mengelola (melihat, edit dan hapus) data hubungan antara kecerdasan dengan ekstrakurikuler.

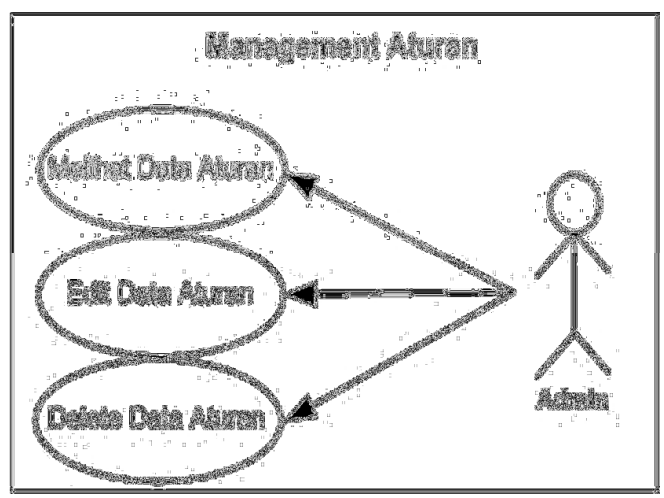

\section{b) Activity Diagram.}

Activity diagram memodelkan alur kerja (work flow) sebuah urutan aktivitas pada suatu proses. Diagram ini sangat mirip dengan flow chart karena kita dapat memodelkan proses logika, proses bisnis dan laur kerja. Perbedaan utamanya adalah flow chart dibuat untuk menggambarkan alur kerja dari sebuah sistem, sedangkan activity diagram dibuat untuk menggambarkan aktivitas aktor.

Berikut akan digambarkan satu persatu activity diagram untuk masing-masing use case.

\section{1) Pendaftaran Anggota}

Activity diagram untuk pendaftaran anggota yaitu proses user menginput form registrasi sampai pada proses notifikasi user telah terdaftar.

- Input Data Anggota

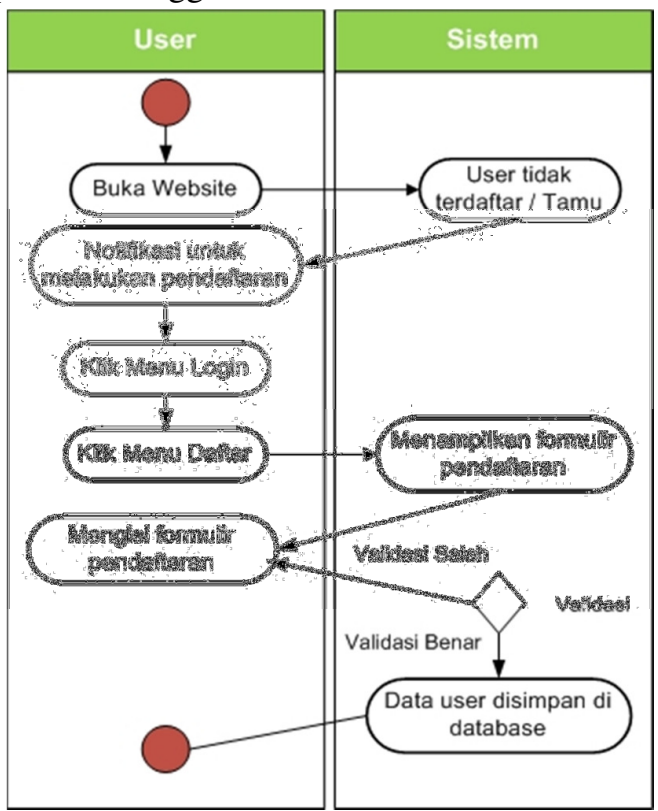


- Notifikasi Status Data Anggota

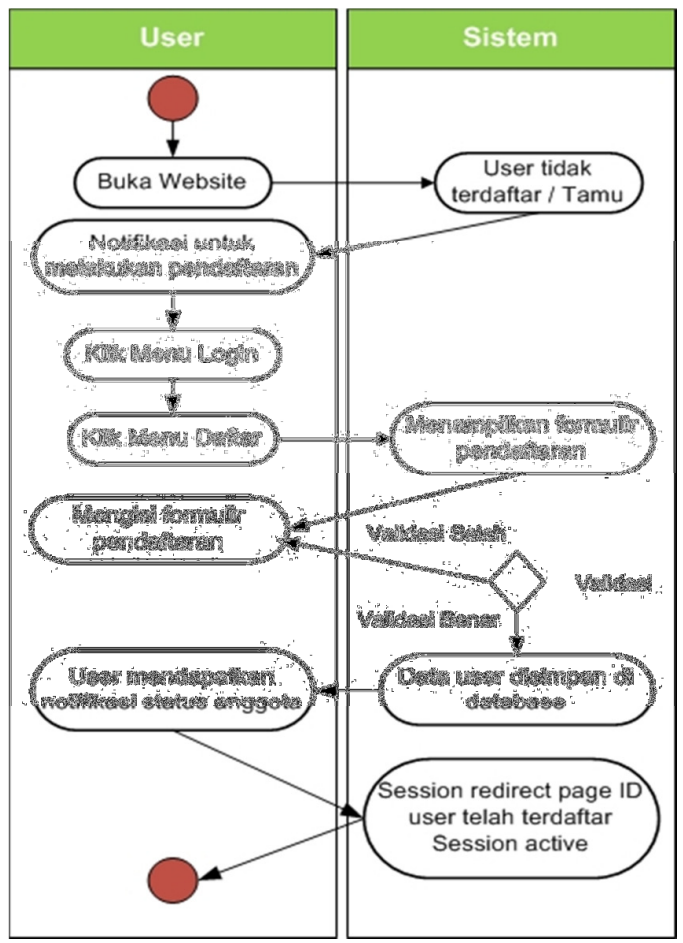

2) Konsultasi Penentuan Ekstrakurikuler

Merupakan aktifitas user melakukan konsultasi sejak menginput kuisioner hinggal output dari system muncul.

- Menjawab Pertanyaan Konsultasi

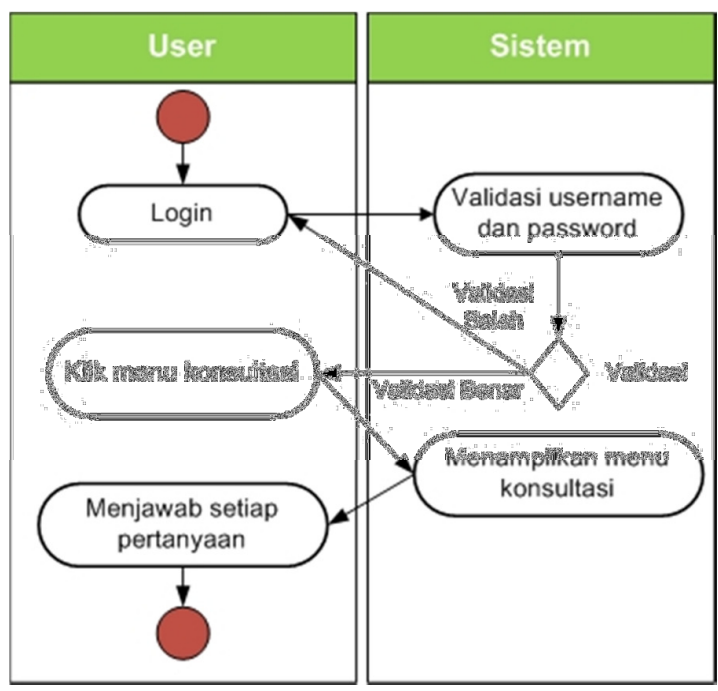

- Melihat Laporan Konsultasi

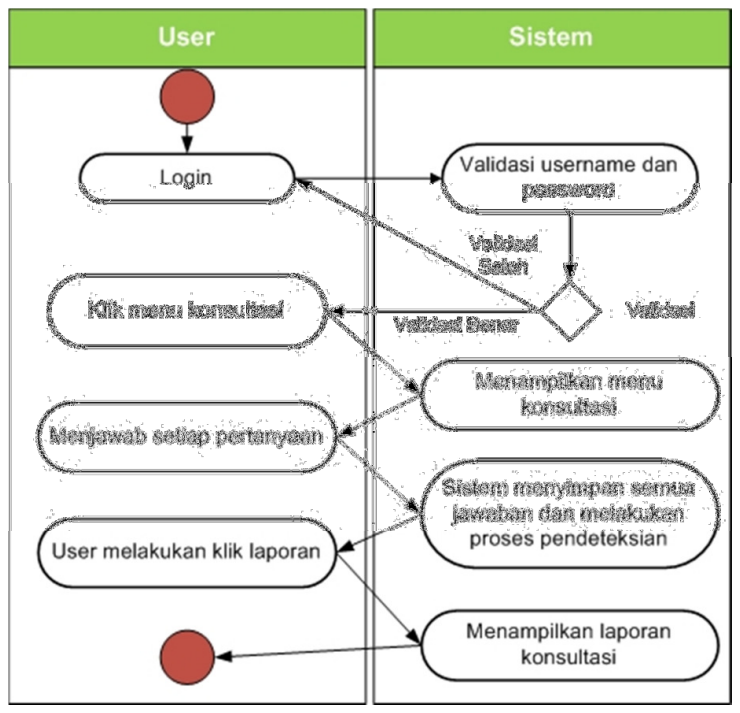

- Melihat Kesesuaian Ekstrakurikuler

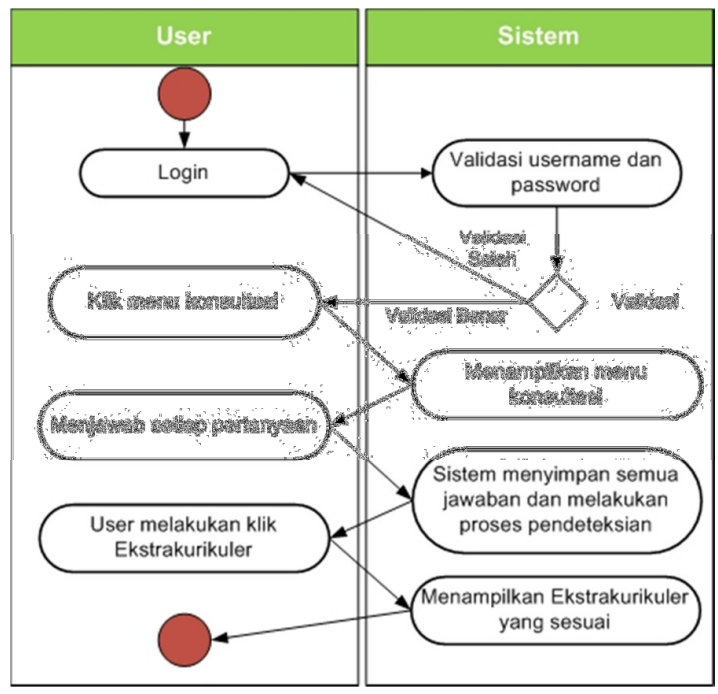

\section{b) Sequence Diagram}

Sequence diagram menggambarkan interaksi antar objek di dalam dan di sekitar sistem (termasuk pengguna, display, dan sebagainya) berupa message yang digambarkan terhadap waktu. Berikut ini adalah sequence diagram untuk masing-masing modul. 
1) Pendaftaran Anggota

- Input Data Anggota

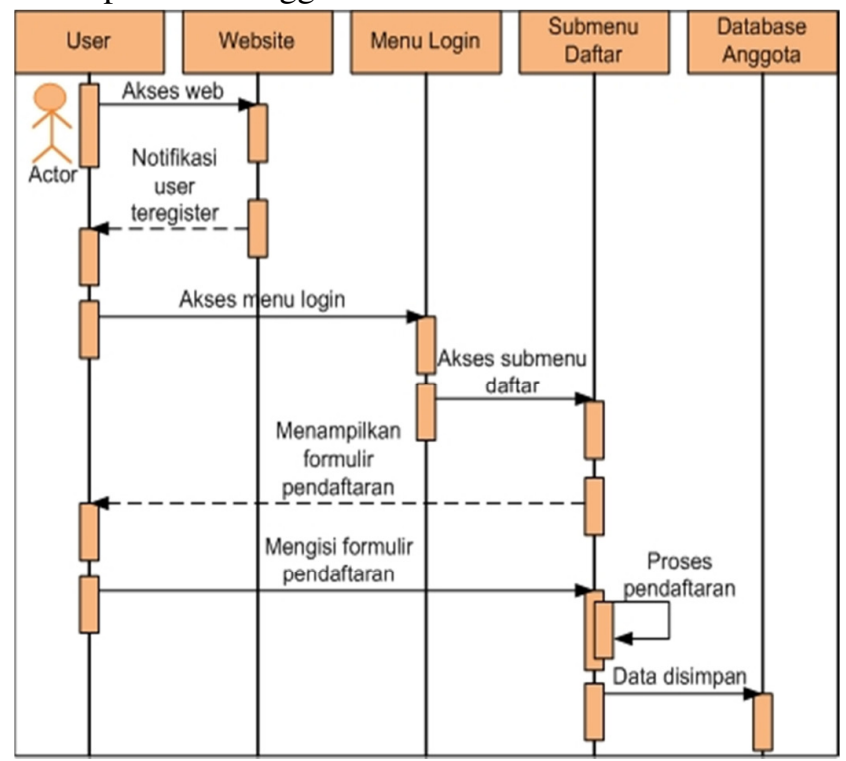

- Notifikasi Data Anggota

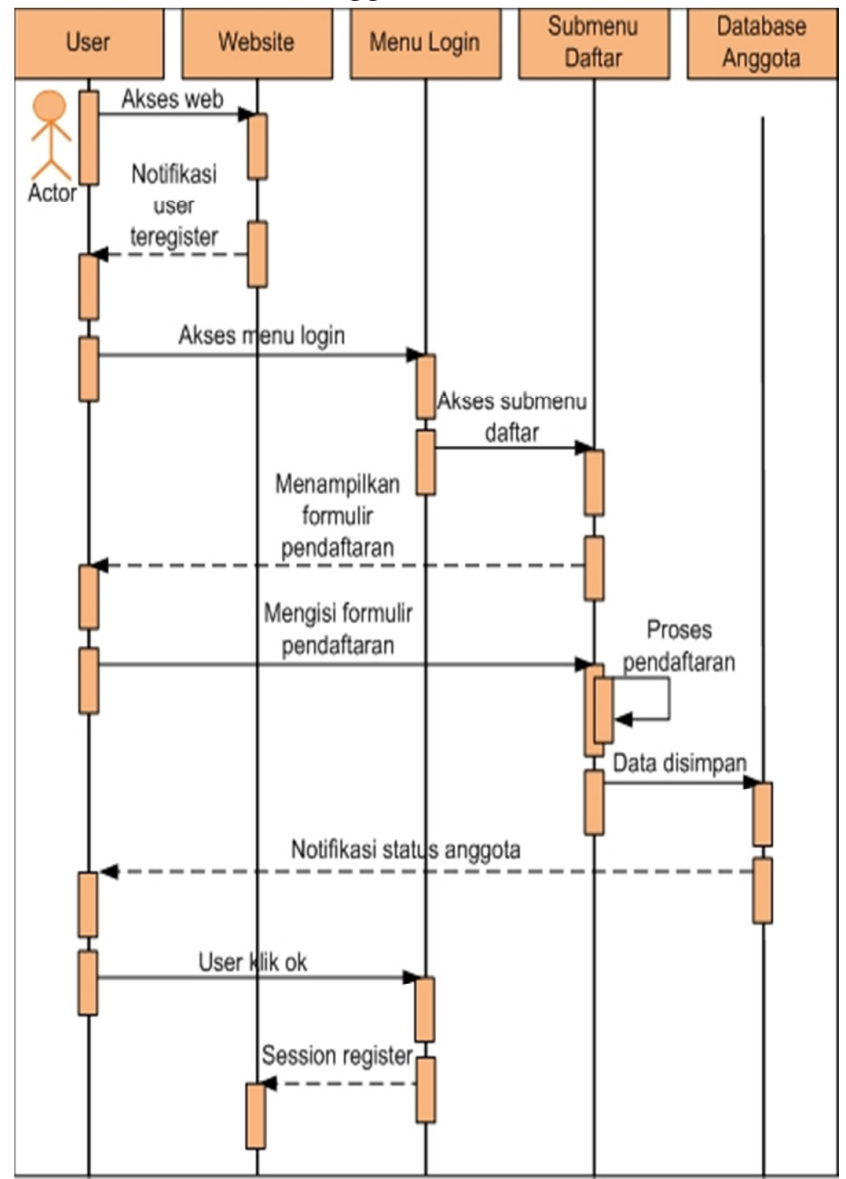

2) Konsultasi Penentuan Ekstrakurikuler

- Menjawab Pertanyaan Konsultasi

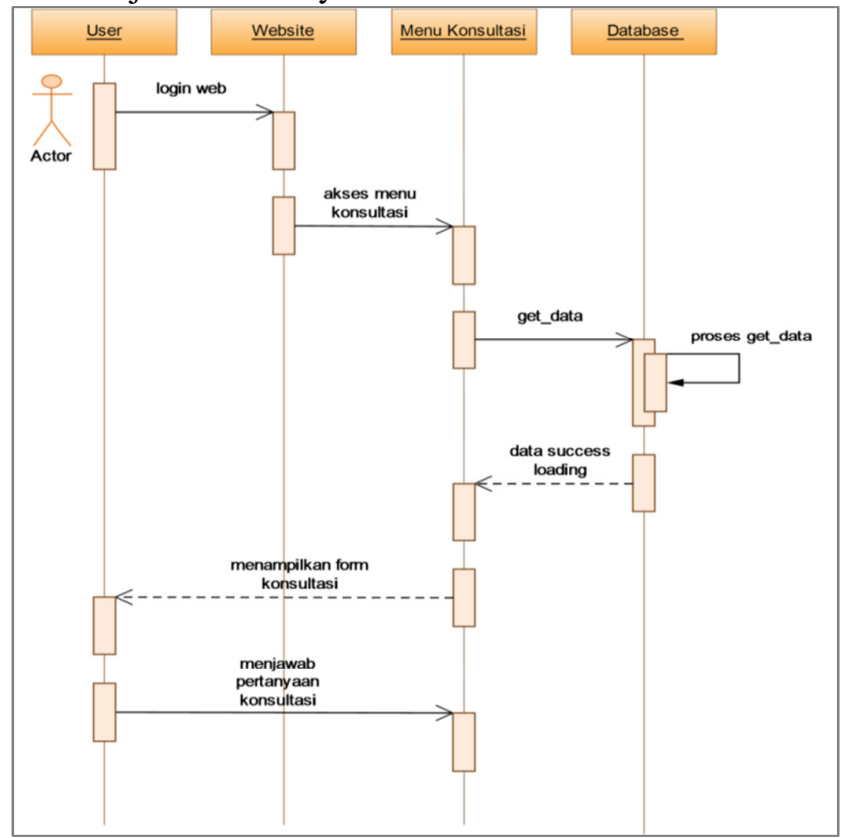

- Melihat Laporan Konsultasi

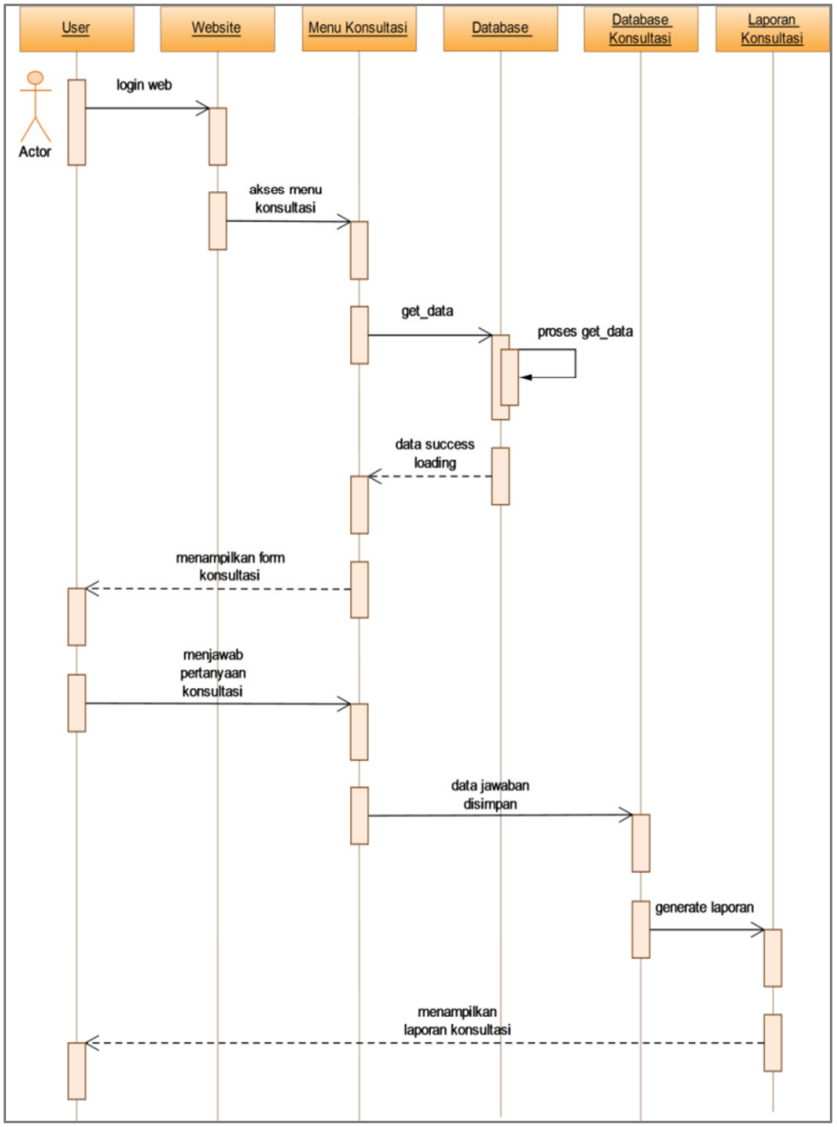


- Melihat Kesesiuaian Ekstrakurikuler

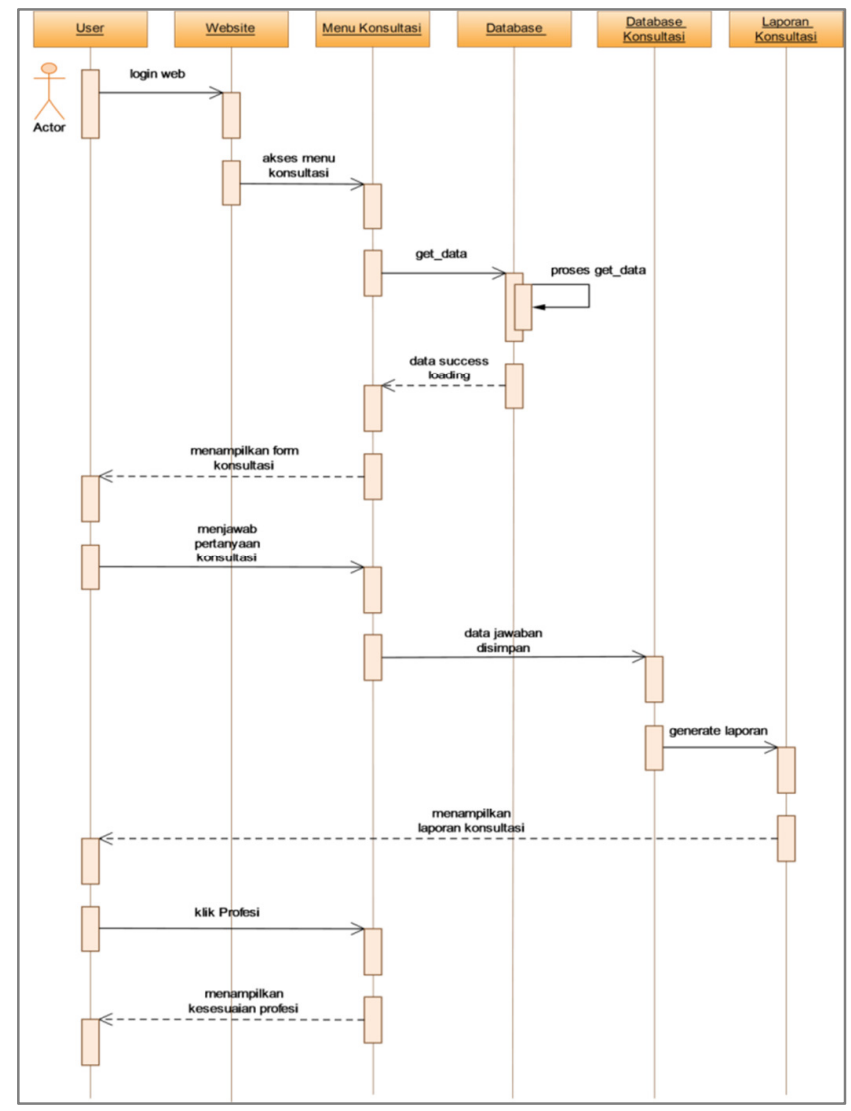

\section{d) Entiti Relationship Diagram}

Merupakan sebuah diagram yang menggambarkan hubungan atau relasi antar entitias (Entity), dan setiap Entity terdiri atas satu atau lebih atribut yang mempresentasikan seluruh kondisi dari yang di tinjau.

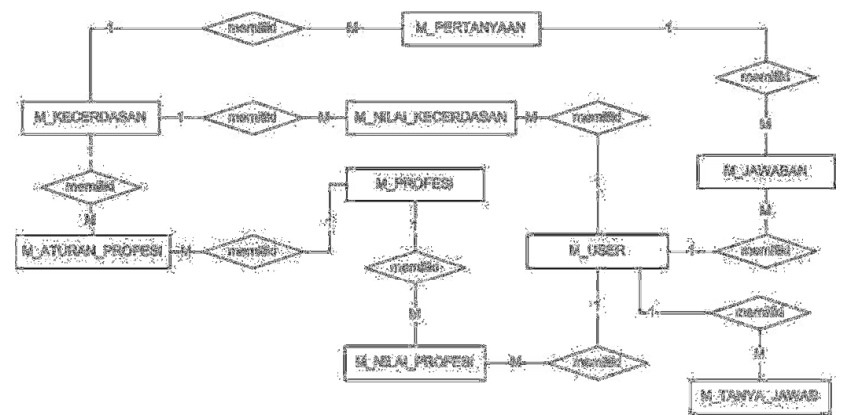

Gambar 7 Model Entity Relationship Diagram

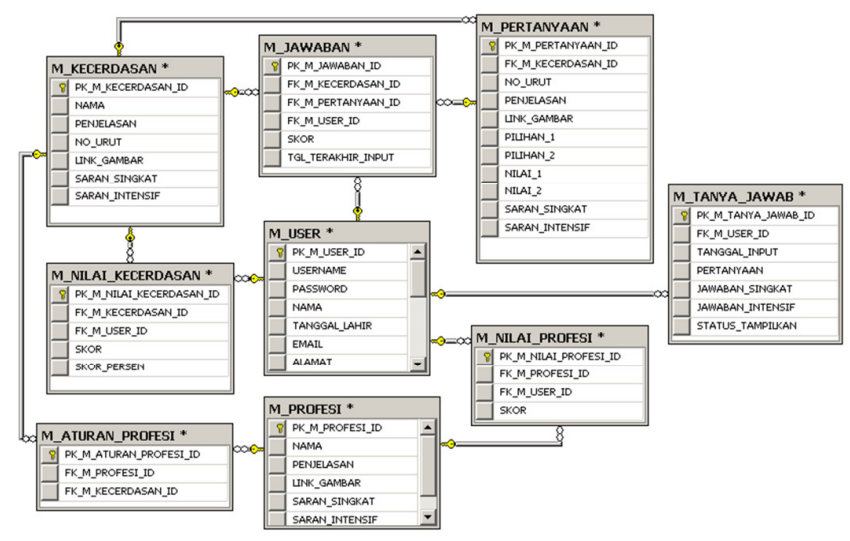

Gambar 8 Model Logical Record Structure

\section{IMPLEMENTASI}

\section{a) Inisialisasi Kasus}

\section{1) Analisa Masalah}

Domain masalah meliputi 5 klasifikasi kecerdasan, yaitu kecerdasan Linguistic, Visual-Spasial, Kinestik, Musikal, dan Naturalis. Kelima klasifikasi ini yang kemudian akan dilakukan analisis masalah dengan cara dibuat beberapa parameter pendekatan yang akan digunakan, berikut ini akan dijelaskan parameterparameter tersebut.

- Kecerdasan Linguistik

Kecerdasan linguistik adalah kemampuan untuk menggunakan kata-kata secara efektif, baik secara lisan maupun tulisan. Kecerdasan ini mencakup kepekaan terhadap arti kata, urutan kata, suara, ritme dan intonasi dari kata yang di ucapkan. Termasuk kemampuan untuk mengerti kekuatan kata dalam mengubah kondisi pikiran dan menyampaikan informasi.

- Visual Spasial

Kecerdasan Visual - Spasial adalah kemampuan untuk membentuk suatu gambaran tentang tata ruang didalam pikiran. Anak. Anak dengan kecerdasan visual-spasial yang tinggi cenderung berpikir secara visual. Mereka kaya khayalan internal (internal imagery) sehingga cenderung imajinatif dan kreatif

- Kinestetik

Elemen dasar dari kecerdasan jasmani-kinestetik adalah kemampuan mengendalikan gerakan tubuh dan kemampuan memainkan obyek dengan terampil. Gardner menjelaskan bahwa kecerdasan ini juga meliputi ketangkasan. jitu, dan kemampuan melatih respons hingga menjadi gerak refleks. Anak dengan kendali motorik halus yang 
baik masuk dalam kategori cerdas kinestetik. Awalnya, kecerdasan ini dianggap remeh.

Ketika Gardner pertama kali menyematkan kata kecerdasan pada kemampuan jasmani, banyak orang yang terkejut. Namun perlahanlahan, semakin banyak orang mengakui jenis kecerdasan kinestetik karena individu-individu yang menciptakan penemuan baru di bidang gerakan olahraga dan tari semakin sering dijumpai. Anak-anak dengan kecerdasan jasmanikinestetik yang menonjol akan menyukai kegiatankegiatan fisik, dapat melakukan sesuatu dengan hanya melihat orang lain melakukannya, serta tidak bisa duduk diam dalam jangka waktu yang lama. Anak dengan kecerdasan kinestetik biasanya menonjol di bidang olahraga dan menari.

- Musikal

Kecerdasan musikal adalah kemampuan individu dalam menggubah lagu dan musik, bernyanyi dan bermain alat musik, dan dapat menghargai semua jenis musik, serta memiliki kepekaan yang kuat akan keserasian dan kesadaran universal tentang berbagai pola kehidupan.

- Naturalist

Merupakan kecerdasan adalah kecerdasan yang dimiliki oleh individu terhadap tumbuhan, hewan dan lingkungan alam sekitarnya. Individu yang memiliki kecerdasan naturali yang tinggi akan mempunyai minat dan kecintaan yang tinggi terhadap tumbuhan, binatang dan alam semesta.

\section{2) Akuisisi Pengetahuan}

Pengetahuan yang menjadi rujukan dalam aplikasi sistem pakar ini berdasarkan kepada pakar Psikologi. Pengetahuan tersebut kemudian diinventarisasi ke dalam bentuk database sehingga akan mudah dalam hal penerjemahan oleh sistem. Sebagai catatan sistem pakar yang akan dibuat adalah sistem pakar untuk mengidentifikasi kecocokan ekstrakurikuler dengan input form konsultasi dengan banyak pertanyaan dalam satu sesi dan setiap pertanyaan memiliki pilihan jawaban (Ya dan Tidak) serta output yang diharapkan adalah skor probabilitas (\%). Maka dari itu perlu dijabarkan basis pengetahuan apa saja yang diperoleh dari pakar, penjabarannya:

- Metode

Tabel Daftar Metode Identifikasi Bakat Siswa

\begin{tabular}{|c|c|}
\hline ID & Nama Metode \\
\hline m001 & Metode Identifikasi Kecerdasan Linguistik \\
\hline m002 & Metode Identifikasi Kecerdasan Visual-Spasial \\
\hline $\mathrm{m} 003$ & Metode Identifikasi Kecerdasan Kinestetik \\
\hline $\mathrm{m} 004$ & Metode Identifikasi Kecerdasan Musikal \\
\hline $\mathrm{m} 005$ & Metode Identifikasi Kecerdasan Naturalis \\
\hline
\end{tabular}

- Pertanyaan

Pertanyaan terkait dengan materi kelima kategori kecerdasan yang telah disebutkan, dan dikodekan dengan $\mathrm{p}(\mathrm{n}), n$ adalah nomor pertanyaan berupa 1 digit angka 1, 2, 3, dan seterusnya. Sehingga akan menjadi p1, p2, p3, dan seterusnya.

- Pilihan Jawaban

Pilihan jawaban terdiri dari jawaban Ya dan Tidak. Isi dari pilihan jawaban disesuaikan dengan pertanyaan yang ditanyakan dengan pendekatan baik, dan buruk serta berdasarkan kepada skala Likert. Berikut ini adalah contohnya.

Pertanyaan: apakah kamu suka membaca?

\author{
Jawaban: \\ Pilihan Ya $\rightarrow$ Ya ( Baik ) \\ Pilihan Tidak $\rightarrow$ Kurang ( Kurang Baik )
}

\section{- Nilai}

Nilai atau skor digunakan untuk mengukur kecerdasan berdasarkan kepada lima kategori bidang metode identifikasi kecerdasan. Nilai disesuaikan dengan pilihan jawaban Ya dan Tidak. Pemberian nilai pada masing-masing pilihan jawaban disesuaikan dengan kaidah pada skala Likert dan diambil dari pengukuran nilai positif (dari Baik ke Kurang Baik) berikut ini adalah penjabarannya:

Nilai 2 diberikan, jika jawaban adalah baik.

Nilai 1 diberikan, jika jawaban adalah kurang baik.

Dengan pemberian nilai pada masing-masing pertanyaan akan diperoleh skor kecerdasan linguistik dengan menggunakan rumus probabilitas klasik pada masing-masing bidang kecerdasan, yaitu dengan cara mengakumulasi nilai tersebut pada tiap-tiap pertanyaan pada tiap bidang kecerdasan. Dan dengan skor kecerdasan tersebut akan terlihat bahwa dengan skor tersebut, siswa dapat dikategorikan memiliki kecerdasan yang BAIK atau KURANG BAIK menggunakan perhitungan skala Likert.

\section{b) Konseptualisasi}

\section{1) Pemilihan Teknik Penalaran}

Teknik Penalaran menggunakan teknik forward chaining, dimana data sudah terdefinisi sebelumnya (data driven) pada basis pengetahuan kemudian mencari kesimpulan/solusi yang tepat. Pada teknik 
penalaran maju (forward chaining) sistem pakar metode kecerdasan, yang menjadi output adalah kesimpulan/solusi, dan yang menjadi input adalah pertanyaan-pertanyaan yang merepresentasi suatu masalah kecerdasan. Jadi penggunaan teknik penalaran maju (forward chaining) adalah dikarenakan sistem akan mencari solusi yang tepat dari masalah yang sudah terdefinisikan.

\section{2) Pemilihan Teknik Penelusuran}

Teknik penelusuran yang dipakai menggunakan teknik depth-first search. Penggunaan teknik depthfirst search adalah dikarenakan sesuai dengan sistem pakar yang dirancang yakni berdasarkan pada jenis pertanyaan yang dipakai yaitu pertanyaan yang cukup dijawab melalui pilihan multiple choice.

\section{3) Pemilihan Teknik Representasi Pengetahuan}

Teknik representasi pengetahuan yang digunakan adalah dengan menggunakan metode kaidah/aturan produksi karena metode ini lebih praktis untuk penyelesaian masalah yang muncul dalam pembuatan sistem pakar. Kaidah produksi yang digunakan adalah kaidah IF-THEN dengan bentuk premis konklusi.

\section{4) Pemilihan Teknik Perhitungan Skor Kecerdasan}

Teknik yang digunakan adalah gabungan antara teknik probabilitas klasik dan juga skala Likert. Probabilitas digunakan untuk menghitung berapa prosentase yang keluar berdasarkan rumus probabilitas klasik, sedangkan perhitungan skala Likert digunakan untuk menentukan apakah prosentase tersebut termasuk ke dalam kategori BAIK atau KURANG BAIK.

\section{c) Formalisasi}

Pada proses mekanisme inferensi mula-mula dibuat pohon inferensi yang terdiri dari node-node yang sudah terdefinisikan berupa variabel-variabel yang digunakan di dalam sistem untuk memudahkan mencari bagian IF terlebih dahulu dari parameter metode kecocokan ekstrakurikuler, Setelah semua kondisi IF dipenuhi, rule (aturan) dipilih untuk mendapatkan kesimpulan. Proses ini akan berlanjut hingga dicapai kesimpulan akhir.

Pada teknik depth first search dilakukan penelusuran data dari parameter metode kecocokan ekstrakurikuler pada node-node yang sudah terdefinisikan berbentuk pertanyaan dari semua rangkaian node secara mendalam sampai ditemukannya kesimpulan.
Setelah itu dibuat representasi pengetahuan berupa aturan produksi dari pohon inferensi yang sudah dibuat, dengan berdasarkan kepada masalah berupa variabel IF dan solusi berupa variabel THEN. Setiap variabel IF dan THEN harus sesuai dengan pengetahuan yang diakuisisi dari pakar.

\section{1) Membuat Pohon Inferensi}

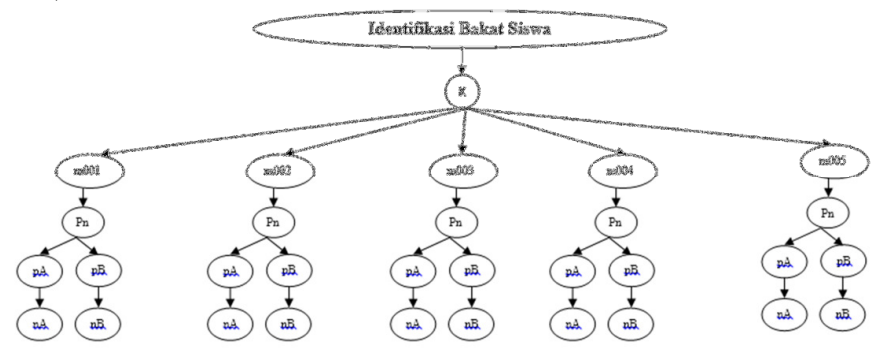

Tabel Variabel Data Pohon Inferensi

\begin{tabular}{|l|l|l|}
\hline K & $:$ & Konsultasi \\
\hline m001 & $:$ & Metode Kecerdasan Linguistik \\
\hline m002 & $:$ & Metode Kecerdasan Visual - Spasial \\
\hline m003 & $:$ & Metode Kecerdasan Kinestik \\
\hline m004 & $:$ & Metode Kecerdasan Musikal \\
\hline m005 & $:$ & Metode Kecerdasan Naturalis \\
\hline pA & $:$ & Pilihan A \\
\hline pB & $:$ & Pilihan B \\
\hline nA & $:$ & Nilai A \\
\hline nB & $:$ & Nilai B \\
\hline
\end{tabular}

2) Membuat Teknik Penelusuran

Teknik penelusuran menggunakan depth-first search pada setiap metode kecerdasan, yaitu:

- Penelusuran pada Metode Linguistik

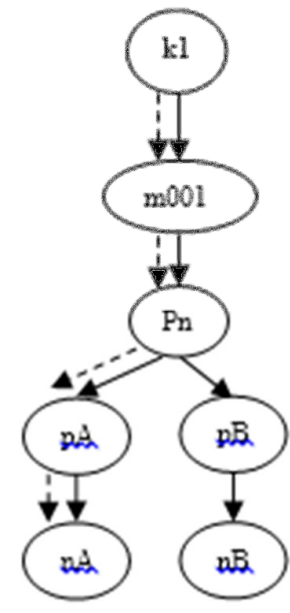


- Penelusuran pada Metode Visual Spasial

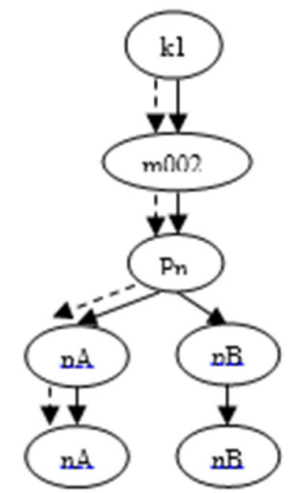

- Penelusuran pada Metode Kinestetik

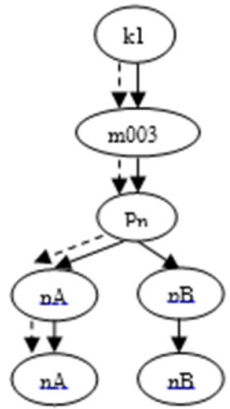

- Penelusuran pada Metode Musikal

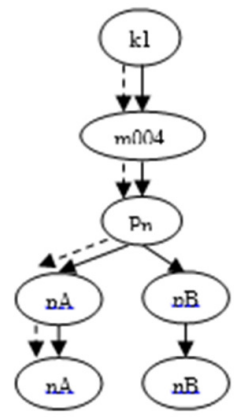

- Penelusuran pada Metode Naturalis

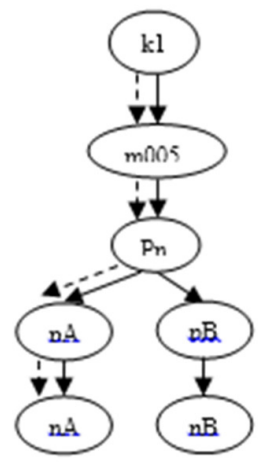

3) Membuat Teknik Perhitungan Skor

Kecerdasan

Probabilitas merupakan instrumen penting sebagai salah satu teknik penyelesaian masalah. Probabilitas merupakan peluang suatu kejadian, yaitu: suatu ukuran tentang kemungkinan suatu peristiwa (event) akan terjadi di masa mendatang. Probabilitas dinyatakan dengan nilai atau dalam prosentase (\%).

Pada aplikasi Sistem Pakar Penentuan Ekstrakurikuler Terhadap Minat dan Bakat SMP, probabilitas pendekatan klasik digunakan untuk menghitung nilai kecerdasan siswa dengan cara menghitung setiap jawaban lalu membaginya dengan banyaknya pertanyaan yang dijawab, kemudian akan terlihat prosentase nilainya. Sedangkan perhitungan skala Likert digunakan untuk menentukan apakah prosentase nilai yang sudah didefinisikan termasuk ke dalam kategori BAIK atau KURANG BAIK, berdasarkan kepada perhitungan dengan skala Likert. Untuk lebih jelasnya mengenai cara menghitung prosentase nilai kecocokan ekstrakurikuler pada sistem dapat dilihat pada contoh berikut ini:

Contoh:

Diketahui dalam Metode Bidang kecerdasan Linguistik (m001), terdapat 5 butir pertanyaan, dengan tiap-tiap pertanyaan memiliki pilihan jawaban Ya dan Tidak, masing-masing pilihan jawaban memiliki nilai 2, dan 1 Maka probabilitas nilai kecerdasannya adalah:

$$
\begin{array}{r}
P(A)=\text { Peluang suatu kejadian } \\
p(n)=\text { Pertanyaan sebanyak } n \\
\text { jumlah pertanyaan }=5 \\
\text { jumlah pilihan }=2
\end{array}
$$

total kemungkinan $=$ jumlah pertanyaan $\times$ jumlah pilihan

$$
\begin{gathered}
P(A)=\frac{\text { total nilai pertanyaan dari pilihan jawaban }}{\text { total kemungkinan }} \\
P(m 002)=\frac{p 1+p 2+p 3+p 4+p 5}{10} \\
P(m 002)=\frac{2+1+2+2+1}{10} \\
P(m 002)=\frac{8}{10} \\
P(m 002)=0,8 \\
\text { Prosentase } P(m 001)=0,8 \times 100 \% \\
\text { Prosentase } P(m 001)=80 \%
\end{gathered}
$$




\section{Menghitung Nilai Kualitatif:}

jumlah pertanyaan $=5$

jumlah pilihan bernilai $=2$

total kemungkinan $=$

jumlah pertanyaan $\times$ jumlah pilihan

skor terendah $=1$ (pilihan jawaban yang tidak)

skor tertinggi $=2$ (pilihan jawaban yang benar $)$

jml skor terendah

$$
\begin{gathered}
=\frac{\text { skor terendah } \times \text { jml pertanyaan }}{\text { total Kemungkinan }} \times 100 \% \\
=\frac{1 \times 5}{10} \\
=50 \%
\end{gathered}
$$

jml skor tertinggi

$$
\begin{aligned}
& =\frac{\text { skor terting } i \times j m l \text { pertanyaan }}{\text { total Kemungkinan }} \\
& \times 100 \% \\
& =\frac{2 \times 5}{10} \\
& =100 \%
\end{aligned}
$$

Penentuan Skoring Pada Kriteria Objektif Rumus Umum :

$$
\begin{gathered}
\text { Interval }(I)=\frac{\text { Range }(R)}{\text { Kategori }(K)} \\
\text { Range }(R)=\text { skor tertinggi }- \text { skor terendah }
\end{gathered}
$$

Kategori $(K)=2$

(banyaknya kriteria yang disusun pada kriteria objektif suatu variabel Kategori yaitu Cukup/Baik dan Kurang/Buruk)

$$
\begin{gathered}
\text { Range }(R)=100 \%-50 \%=50 \% \\
\text { Interval }(I)=\frac{50}{2}=25 \% \\
\text { Kriteria Penilaian }=\text { skor tertinggi }- \text { Interval } \\
\text { Kriteria Penilaian }=100 \%-25 \% \\
\text { Kriteria Penilaian }=75 \% \\
\text { Cukup/Baik,Jika Skor }>=75 \% \\
\text { Kurang/Buruk,Jika Skor }<75 \%
\end{gathered}
$$

Berdasarkan perhitungan probabilitas klasik telah diketahui bahwa prosentasenya adalah $80 \%$, dari prosentase tersebut dapat terlihat bahwa $80 \%$ adalah termasuk dalam kriteria penilaian BAIK, dikarenakan $80 \%$ lebih dari $75 \%$.

\section{KESIMPULAN DAN SARAN}

\section{Kesimpulan}

Setelah merancang dan membangun Sistem Pakar Penentuan Ekstrakurikuler Terhadap Minat dan Bakat Siswa SMP ini, maka dapat disimpulkan bahwa dengan adanya aplikasi ini dapat membantu para penggunanya dalam menentukan ekstrakurikuler yang cocok berdasarkan kecerdasan dan bakat yang dimilikinya.

\section{Saran}

Dalam merancang suatu aplikasi tidak lepas dari namanya kesalahan dan kekurangan, begitupula dengan aplikasi Sistem Pakar Penentuan Ekstrakurikule ini. Saran yang perlu dikembangkan dan diperbaiki diantaranya: perlu pengembangan sistem secara berkala sesuai dengan penggunanya dan juga disesuaikan dengan kebutuhan, mengingat aplikasi ini adalah aplikasi sistem pakar yang akan terus menerus mengalami perubahan knowledge (pengetahuan).

Aplikasi Sistem Pakar Penentuan Ekstrakurikuler Terhadap Minat dan Bakat Siswa SMP diharapkan dapat menjadi salah satu media pendukung dalam menentukan bakat anak sejak dini, sehingga dapat mengasah bakat yang dimiliki siswa sejak dini.

Akhir kata dengan pembuatan aplikasi sistem pakar ini Insya Allah semua pihak dapat merasakan manfaatnya terutama bagi para guru tingkat SMP.

\section{DAFTAR PUSTAKA}

[1] Andi. 2003. Pengembangan Sistem Pakar Menggunakan Visual Basic, Edisi 1. Yogyakarta: ANDI

[2] Arhami, Muhammad. 2005. Konsep Dasar Sistem Pakar. Yogyakarta: ANDI

[3] Burhanuddin, Luthfy. 2004. Aplikasi Sistem Pakar Untuk Mendiagnosa Penyakit Mata. UIN Jakarta: Skripsi tidak diterbitkan

[4] Dr. David A. Sousa, "Bagaimana Otak yang berbakat Belajar," Edisi kedua, 2012.

[5] Hoeve, M., Dubas, J.S., Eichelsheim, V.I., Laan, P.H., Smeenk, W., Gerris, J.R.M. 2009. The Relationship Between Parenting and Deliquency: A Meta-Analysis. Journal Abnormal Child Psychology, 37, 7 49-775. 